\title{
The Inauguration of Asian Pacific Journal of Cancer Care
}

\section{The Editorial Team}

West Asia Organization for Cancer Prevention (APOCP's West Asia Chapter)

$$
\text { Asian Pac J Cancer Care, } 1 \text { (1), 1-1 }
$$

On behalf of the Asian Pacific Organization for Cancer Prevention (APOCP) and its subsidiary (the West Asia Organization for Cancer Prevention- WAOCP), it is a great honor to present the inaugural issue of Asian Pacific Journal of Cancer Care (APJCC, ISSN ).

APJCC is branching out from Asian Pacific Journal of Cancer Prevention to become the journal of choice for the large community researchers in the Asian and Pacific region who work on the care cancer patients. Its goal is to become leading online forum to disseminate the work of Asia and Pacific Regions' cancer clinicians to the global audience.

APJCC inherits its inception from the backbone of 17 years of successful publication of the Asian Pacific Cancer Prevention (APJCP) and considers itself as a sister publication of the APJCP.

After 17 years of publication, the APJCP's citation performance based on online portals $[1,2,3]$ is an honored achievement for the board and associated scientists of APJCP. In 2015, APJCP's H-index ranked 47 among 322 cancer-related journals worldwide. This figure was higher than the median $\mathrm{H}$-index for all cancer-related journals (median 27). The APJCP's SCImago Journal Rank or SJR (defined as the average number of weighted citations received in the selected year by the documents published in the selected journal in the three previous years) for 2015 was 0.85 . This figure was close to the median figure reported for journals published in Western Europe (median of 0.85 ) and lower than the median SJR for journals of the same category in the region of North America (median of 1.07). In 2015, the Source Normalized Impact per Publication indicator (SNIP- calculated as the number of citations given in the present year to publications in the past three years divided by the total number of publications in the past three years) for APJCP was 0.87 . This is slightly higher than the median for all cancer-related journals that was 0.79 . The Impact per Publication (IPP) was 2.06 for APJCP while this indicator's median for all cancer-related journals was 2.04.

In June 2016, a new editorial team took the full responsibility of the APJCP and a roadmap was set up for the journal. Among the many challenges facing the journal, the editorial team prioritized three goals to reach in the first two years of operations. One of the goals was to
Submission Date: 11/11/2016 Acceptance Date: 12/25/2016

address the very wide scope of APJCP that was covering a spectrum specialty from cell to society.

The APJCP, traditionally, has published in almost all areas of cancer sciences and specialties from stem cell and molecular aspect to quality of life and end of life issues. The wide spectrum of scope, practically, brought more demand for publishing and causing the large increase in the number of articles per issue (this contributed to the journal's being dropped from Expanded SCI indexing (Moore, 2014)). At present, and as usual to the journal's past, the new editorial team receives a large number of submissions in a very wide spectrum of cancer science. While one solution to this problem was to organize the journal into more sections and keep the journal intact as usual (continue facing huge number submissions), there was another alternative to manage the scope into four areas of cancer sciences; 1) cancer biology, 2) treatment and clinical aspect, 3) epidemiology and prevention, and 4) carcinogens and environmental hazards.

Publication of the Asian Pacific Journal of Cancer Care is serving the goal of organizing the submissions to more specialized scope.

The APJCC's frequency of publishing is a volume each year and four issues per each volume.

The editorial team has set up a millstone of being indexed in PubMed by the first quarter of 2018.

\section{References}

1. CWTS journal indicators, Leiden university's centre for science and technology studies, Retrieved Dec 20, 2015, from http://www.journalindicators.com/indicators, Elsevier, Scopus Sources, Retrieved Dec 20, 2015, from https://www. scopus.com.

2. Moore MA (2015). APJCP loss of SCI expanded listing and the future of the journal. Asian Pac J Cancer Prev, 16, 4145-6

Mosavi Jarrahi A, Moore MA, Huang X, Roder D (2016). Asia pacific journal of cancer prevention MEDLINE/PubMed listing and solution to the PRESERVATION issue. Asian Pac J Cancer Prev, 17 , 4549-51.

3. SCImago (2007). SJR - SCImago journal and country rank. retrieved july 21, 2015, from http://www.scimagojr.com

This work is licensed under a Creative Commons AttributionNon Commercial 4.0 International License.

\footnotetext{
Corresponding Author:

Dr. Alireza Mosavi Jarrahi

Medical School, Shahid Beheshti University of Medical Sciences, Tehran, Iran.

Email: rmosavi@yahoo.com
} 